\begin{tabular}{|c|c|c|}
\hline \multirow{2}{*}{$\begin{array}{l}\text { EREM 76/4 } \\
\text { Journal of Environmental Research, } \\
\text { Engineering and Management }\end{array}$} & \multicolumn{2}{|c|}{ Circular Economy: Can Belarus Close the Loop? } \\
\hline & Received 2019/10 & Accepted after revision 2020/10 \\
\hline $\begin{array}{l}\text { pp. 7-19 } \\
\text { Dol 10.5755/j01.erem.76.4.24433 }\end{array}$ & \multicolumn{2}{|c|}{ crossef http://dx.doi.org/10.5755/j01.erem.76.4.24433 } \\
\hline
\end{tabular}

\title{
Circular Economy: Can Belarus Close the Loop?
}

\section{Siarhei Zenchanka*, Nadzezhda Antsipenka, Dmitrij Busygin}

Minsk Branch of Plekhanov Russian University of Economics, 40, Radialnaya Str. Minsk, 220070, Belarus

\section{Elena Korshuk}

Belarussian State University, 4, Nezavisimosti Avenue, 220030, Minsk, the Republic of Belarus

\section{Henry Sidsaph}

Business Research Institute University of Chester, Riverside Campus, Castle Drive, Chester, United Kingdom, CH11SL

\section{*Corresponding author: zench@tut.by}

As the world economy attempts to move towards a circular economy, the Republic of Belarus has adopted its "National Strategy for Sustainable Development for the period to 2030" and "National Plan of Action for the Green Economy", thereby taking the first steps towards creating a circular economy. The purpose of this article is to understand the potential of applying the principles of the circular economy to the economy of the Republic of Belarus. This is the first known article that has directly studied the state of Belarus' transaction towards a circular economy. This article's findings are based on analyzing the main articles and reports related to the circular economy literature and by analyzing the state of Belarus' economy in the context of transitioning from a "green" to a "circular" economy. In Belarus, there are some successes in areas of their circular economy transition, such as recycling plastic and construction wastes; however, other areas require further development. A potential limitation of this study is that it only analyzed the main works on the definitions and principles of the circular economy, and therefore wider research may be needed.

Keywords: Circular Economy, Sustainable Development, Green Economy, Definition, Principle 


\section{Introduction}

"Money is the measure of all worth and the source of all happiness.

Earth is simply a source of raw materials. Inequality and environmental destruction are unfortunate but unavoidable."

David C. Korten (2015)

The first reports of the Club of Rome (Forrester, 1971; Meadows, 1972) sparked a heated discussion, both among sociologists and among politicians. Economists pointed out that the scientific and technological revolution accelerates not only the consumption of non-renewable resources and the pollution of the environment, but also the development of new resources, the introduction of resource-saving and environmentally friendly technologies.

Hereinafter, the authors of the report to the Club of Rome began to focus not on the description of future threats, but on the analysis of ways to prevent them. Von Weizsäcker et al. (1998), having analyzed the development of resource-saving technologies, concluded that instead of a global catastrophe after 2050, the simultaneous stabilization of the population and industrial production can be expected while reducing the level of environmental pollution. The next report (von Weizsäcker et al., 2009) pointed out that "the 21 st century will see monumental change. Either the human race will use its knowledge and skills and change the way it interacts with the environment, or the environment will change the way it interacts with its inhabitants. In the first case, we would use the sophisticated understanding in areas such as physics, chemistry, engineering, biology, commerce, business and governance that we have in the last 1000 years to bring to bear on the challenge of dramatically reducing our pressure on the environment. The second case, however, is the opposite scenario. It will involve the decline of the planet's ecosystems until they reach thresholds where recovery is not possible". As a result, the report showed that Factor Five or 80 percent reduction of environmental impacts per unit of economic output is available.

In a recent report to the Club of Rome Wijkman and Skånberg (2016) indicated that "Both governments and businesses are beginning to realize that our linear systems of resource use expose both societies and businesses to a number of serious risks. Resource constraints as well as increasing volumes of waste and pollution are likely to impose increasing threats to welfare and wellbeing and, from a business point of view, to competitiveness, profits and business continuity". At the same time, "the circular economy as a concept implies recycling, reuse and would be strengthened by extending the use-life of products".

The idea of Sustainable Development was suggested in the Brundtland Report (1987), and the Sustainable Development Concept for the 21st century was suggested during the United Nations Conference on Environment and Development (UNCED), Rio de Janeiro, 3-14 June 1992 (Agenda 21, 1992).

The next remarkable step in Sustainable Development was made during the Rio+20 Conference in 2012. The Declaration (2012) of this conference "The future we want" considers "green economy in the context of sustainable development and poverty eradication as one of the important tools available for achieving sustainable development and that it could provide options for policymaking but should not be a rigid set of rules". In recent years, the green economy was further developed. Various aspects of the green economy have been discussed in documents by international organizations such as the United Nations Environmental Program (UNEP, 2011; UNEP, 2015; UNEP, 2016; UNEP, 2017), Partnership for Action on Green Economy (PAGE, 2016; PAGE, 2017, PAGE, 2018).

The United Nations Department of Economic and Social Affairs (UNDESA) published four issues of "A Guidebook to the Green Economy" (UNDESA, 2012a, 2012b, 2012c, 2013). The first issue (UNDESA, 2012a) considers the history of the green economy concept. In particular, it pointed out that the term "green economy" was first used in 1989 in a report for the Government of the United Kingdom by a group of leading environmental economists, entitled "Blueprint for a Green Economy" (Pearce, Markandya and Barbier, 1989). This issue also includes references to approximately 90 different green economy publications. The subsequent publications of UNDESA suggested eleven principles for a green economy (UNDESA, 2012b), 
review of ten national strategies for the green economy, green growth and low-emission development (UNDESA, 2012c) and initiatives for implementing green economy principles (UNDESA, 2013).

In 2015, the UNEP presented a report describing initial findings in sustainable development from the Global South, one part of which describes the transition to a green economy in South Africa (UNEP, 2015). The report underlines that "there is no denying that the Green Economy discourse is now an integral part of South Africa's policy and strategy discussions, both within the three spheres of government and also extending into the private sector. Besides that, various groups are developing indicators to measure transition progress and also to direct the development of capacity and capabilities".

In its report, the OECD (2017) pointed out that "several countries are at the forefront of the transition towards green growth, but no country leads in all areas".

Despite the remarkable steps in the green economy the problem of waste generation is remaining. To overcome this problem, the concept of a circular economy was proposed.

The Republic of Belarus has poor fuel mineral resources such as gas, oil and coal and its economy highly

Table 1. Energy dependence of the Republic of Belarus (thousand tons of fuel equivalent or coal equivalent). (Statistical book, 2019)

\begin{tabular}{l|c|c|c|c}
\hline \multicolumn{1}{c|}{ Year } & 2010 & 2016 & 2017 & 2018 \\
\hline $\begin{array}{l}\text { Own fuel and energy } \\
\text { resources }\end{array}$ & 5766 & 5270 & 5665 & 5984 \\
\hline $\begin{array}{l}\text { Import of fuel and } \\
\text { energy resources }\end{array}$ & 48707 & 51036 & 51750 & 52909 \\
\hline
\end{tabular}

depends on their supply and price. Table 1 presents data on the energy independence of Belarus.

The changes in the production of own resources and imports of such resources are approximately $9 \%$.

The problem of high energy and material consumption of production is urgent. This requires changes in the structure of the economy, lower energy and resource consumption, i.e., transaction to model of responsible production and consumption in accordance with SDG 12 and affordable and clean energy in accordance with SDG 7 (Platform 2015). The path for such transformation is the implementation of the principles of green and circular economies. The Republic of Belarus has adopted the National Plan (2016) of the transition to a green economy, while the transition to a circular economy as a national concept is not yet considered

The aims of this article are:

To consider the circular economy concept;

To estimate Belarus' achievement in the circular economy.

\section{Methodology}

This article conducted a literature review of relevant academic publications, which focused on the circular economy in the context of sustainability. Sources were obtained from a cross section of interdisciplinary journal publications, as well as pertinent online sources of grey literature such as Governmental Documents, Intergovernmental online repositories (For example the European Commission and the World Bank).

To analyse the development of the Republic of Belarus the databases of the National Statistical Committee (Statistical book, 2019; Statistical Yearbook, 2020) and the Ministry of Natural Resources and Environmental Protection (National Plan, 2016; Review, 2016) were used. Database of National Statistical Committee contains information on economy, industry, energy, environment, including green growth indicator and SDG indicator achievement. In its turn, database of Ministry of Natural Resources and Environmental Protection contains information on protection of natural resources, development of resource base, waste management, etc.

As indicators of an achievement of circular economy results, the indicators of an EU Action plan for the Circular Economy were used. The indicators of the Republic of Belarus compared with European one. This study presents an analysis of the changing of economic concepts of sustainability from green to a circular economy during the last decades. Case studies present some Belarusian experiences in implementing the principles of the circular economy in different areas of economics. This paper has the following structure: Section Introduction; Section Methodology provides details about the method used for the literature selection; Section 
Circular economy concepts gives a summary of the studied literature, provides the definition and concept of a circular economy, describes the principles of a circular economy, and presents the indicators of a circular economy; Section Case studies: Belarus experience in circular economy describes the current state of implementation of a circular economy in the Republic of Belarus, and Section Conclusions summarizes this study's main outcome.

The limitations of the study are that only the main works devoted to the definitions and principles of the circular economy were analysed, since the purpose of the work is to analyse the possibilities of including the principles of the circular economy in the economics of the Republic of Belarus.

\section{Circular economy concepts}

As was cited in Witjes and Lozano (2016), the concept of the circular economy is nothing new; it was suggested in 1928 by W. Leontief. Nova days, therefore it is an established concept. However, in order to discuss this concept and its effects on the environment, it is necessary to understand the definitions and principles of circular economy.

\section{Definitions of a circular economy}

Although around for almost a century, the concept of a circular economy has become more widespread in recent years, as a result many authors have provided slightly different definitions. For example, in their review of the circular economy, Kirchherr et al., (2017) gathered 114 circular economy definitions from 148 articles. Analysing each article, the authors concluded that length of definitions could alter considerably on an individual and journal level. Although there are many definitions to consider, this article considers seven pertinent definitions that are consistently cited in the literature.

When examining the transaction from a linear economy to the circular economy, 10 'R-strategies' have been presented in two recent reviews as a conceptual framework (Kirchherr et al., 2017; Potting et al., 2017). Each 'R' represents a different circular economy word, which is applicable to the overall concept of the circular economy: R0 Refuse, R1 Rethink, R2 Reduce, R3 Reuse, R4 Repair,
R5 Refurbish, R6 Remanufacture, R7 Repurpose, R8 Recycle, and finally R9 Recover. We see that R0 to R7 correspond the circular economy with "smaller product use and manufactures", R8 and R9 correspond linear economy with "useful application of materials" (Kirchherr et al., 2017). However, it should be noted, that all strategies are concerned with minimizing or eliminating waste.

Kirchherr et al., (2017) suggested next definition of the circular economy to consider.

"A circular economy describes an economic system that is based on business models which replace the "end-oflife" concept with reducing, alternatively reusing, recycling and recovering materials in production/distribution and consumption processes, thus operating at the micro level (products, companies, consumers), meso level (eco-industrial parks) and macro level (city, region, nation and beyond), with the aim to accomplish sustainable development, which implies creating environmental quality, economic prosperity and social equity, to the benefit of current and future generations".

One more definition of the circular economy has been provided by Ellen MacArthur Foundation (EMAF) (2012):

"A circular economy is an industrial system that is restorative or regenerative by intention and design. It replaces the "end-of-life" concept with restoration, shifts towards the use of renewable energy, eliminates the use of toxic chemicals, which impair reuse, and aims for the elimination of waste through the superior design of materials, products, systems, and, within this, business models".

Korhonen et al., (2018a), in their analysis of circular economy definitions, divided them into two main areas - based on an EMAF definition and based on own or other researchers' definition. Their definition of circular economy is:

"Circular economy is a sustainable development initiative with the objective of reducing the societal production-consumption systems' linear material and energy throughput flows by applying materials cycles, renewable and cascade-type energy flows to the linear system. Circular economy promotes high value material cycles alongside the more traditional recycling and develops systems approaches to the cooperation of producers, consumers and other societal actors in sustainable development work". 
Another article, Korhonen et al. (2018b), critically considers the concept of a circular economy from the perspective of sustainable development and its three dimensions, economic, environmental and social; therefore suggesting the next definition for a circular economy:

"Circular economy is an economy constructed from societal production-consumption systems that maximizes the service produced from the linear nature-society-nature material and energy throughput flow. This is done by using cyclical material flows, renewable energy sources and cascading1-type energy flows. Successful circular economy contributes to all the three dimensions of sustainable development. Circular economy limits the throughput flow to a level that nature tolerates and utilizes ecosystem cycles in economic cycles by respecting their natural reproduction rates".

All of these definitions are based on the renewing of the production-consumption system and directed towards high-value material cycles. Nevertheless, Korhonen et al. (2018b) identified six challenges for the circular economy concept in terms of environmental sustainability: Thermodynamic limits; System boundary limits; Limits posed by the physical scale of the economy; Limits posed by path-dependency and lock-in; Limits of governance and management; Limits of social and cultural definitions. The authors suggested accepting these challenges as research themes.

In 2015, the European Commission adopted an EU Action Plan (2015) for the circular economy, which identified "the transition to a more circular economy, where the value of products, materials and resources is maintained in the economy for as long as possible, and the generation of waste minimized, is an essential contribution to the EU's efforts to develop a sustainable, low carbon, resource efficient and competitive economy. Such transition is the opportunity to transform our economy and generate new and sustainable competitive advantages for Europe". This definition based on including a new waste hierarchy in the waste treatment process (Briefing, 2018).

\section{Principles of circular economy}

Kirchherr et al., (2017) defined circular economy within the iteratively developed coding framework as an economic system that replaces the "end-of-life" concept by reducing, alternatively reusing, recycling and recovering materials in production/distribution and consumption processes. A circular economy operates at the micro level (products, companies, consumers), meso level (eco-industrial parks) and macro level (city, region, nation and beyond), with the aim to accomplish sustainable development; thus simultaneously creating environmental quality, economic prosperity and social equity, to the benefit of current and future generations.

In 2017 the British Standard Institute published the new standard BS 8001:2017 “Framework for implementing the principles of the circular economy in organizations - guide", which was developed to meet these mutually beneficial goals by providing guiding principles for organizations to deliver more sustainable resource management. The principles of this standard were discussed by Pauliuk (2018). The standard establishes a minimal set of six circular economy principles that all organizations should refer to: system thinking, stewardship, transparency, collaboration, innovation, and value optimization. "Systems thinking" is defined in the standard as an understanding of how organizations, individual decisions and activities interact within the wider systems they are part of.

French the XP X30-901 circular economy project management standard is a fully-fledged tool to be widely employed in the different type of organization such as health services, fertilizer production, organic agriculture, construction industry, etc. Its principle permits easy identification of a whole host of improvements aimed at accelerating the transition to a circular economy (AFNOR standardization, n.d.).

The European Commission recognized that European Standards are essential complementing tools to EU legislation for a circular economy and requested the three European Standardization Organizations - CEN, CENELEC and ETSI - to develop standards to support Eco-design requirements on material efficiency aspects for energy-related products, covering the following aspects: extending product lifetime, ability to reuse components or recycle materials from products at end-of-life, use of reused components and/or recycled materials in products (Brief News 2019).

Natalie Mouyal (2020) pointed, that "the circular economy calls for a radical shift in production and consumption. Continual cycles recover and restore products, components and materials through strategies such 
as reuse, repair, remanufacture and, ultimately, recycling. It is a systemic approach to managing resources" and consider several IEC standards directed to circular economy achievement.

Kalmykova et al. (2018) presented an analysis of circular economy approaches and suggested the use of two developed cross-referenced databases as tools for the implementation of a circular economy: Strategic database on circular economy (including 45 different strategies for different parts of the value chain), and Implementation database - for a circular economy describing over 10 case studies for the 35 strategies.

\section{Indicators for a circular economy}

European Academies Science Advisory Council in policy report (EASAC, 2016) proposed six types of indicators potentially relevant to the circular economy:

Sustainable development;

Environmental;

Material flow;

Societal behaviour;

Organisational behaviour; and

Economy performance.

Besides that, this report points out that "while currently direct links between the CE Action Plan and SDGs are limited, the Commission is right to see potential for synergy between CE indicators and SDGs as a factor to be considered in the selection of indicators".

As was mentioned above, the European Commission adopted an EU Action Plan for the Circular Economy. This Action Plan defines key areas of implementation as:

Plastics;

Food waste;

Critical raw materials;

Construction and demolition;

Biomass and bio-based products.

Based on the new waste hierarchy, this Action Plan includes the next key elements (Action Plan, 2015):

A common EU target for recycling $65 \%$ of municipal waste by 2030;

A common EU target for recycling $75 \%$ of packaging waste by 2030 ;
A binding landfill target to reduce landfill to a maximum of $10 \%$ of municipal waste by 2030 ;

A ban on landfilling of separately collected waste;

Promotion of economic instruments to discourage landfilling;

Simplified and improved definitions and harmonized calculation methods for recycling rates throughout the EU;

Concrete measures to promote re-use and stimulate industrial symbiosis - turning one industry's by-product into another industry's raw material;

Economic incentives for producers to put greener products on the market and support recovery recycling schemes (e.g. for packaging, batteries, electrical and electronic equipment, vehicles).

To highlight the significance of the EU Action Plan, in 2018 more than 10 documents were adopted for realisation Circular Economy Package (2018):

EU Strategy for Plastics in the Circular Economy Communication;

EU Strategy for Plastics in the Circular Economy Staff Working Document;

EU Strategy for plastics in the Circular Economy Brochure;

Strategy for plastics;

Factsheets on the strategy for plastics in a circular economy:

Factsheet - changing the way we use plastics;

Communication on the Interface between chemicals, products and waste legislation;

Monitoring framework for the circular economy;

Proposal on Port Reception;

Report on critical raw materials;

Report on oxo-plastics;

Eurobarometer: SMEs and the circular economy.

These documents help European States implement the circular economy principles in practice. To assess the degree of progress towards a cyclical economy, one should use the "Monitoring framework for the circular economy" (Communication, 2018). As noted by this document, "in the transition to a more circular economy, monitoring the 
key trends and patterns is key to understanding how the various elements of the circular economy are developing over time, to help identify success factors in Member States and to assess whether sufficient action has been taken". Ten key indicators were suggested in four areas:

Production and consumption:

EU self-sufficiency for raw materials;

Green public procurement;

Waste generation:

Food waste;

Waste management:

Overall recycling rate;

Recycling rates for specific waste streams;

Secondary raw materials:

Contribution of recycled materials to raw materials demand;

Trade in recyclable raw materials;

Competitiveness and innovation:

Private investments, jobs and gross value added;

Patents.

The Republic of Belarus has no significant natural resources, except potash fertilizer, peat and minor oil fields, and strongly depends from import of fuel and ferrous and non-ferrous metals. Hence, the priority goal for Belarus is decreasing the dependence from outer provider and transit to green and circular economies.

\section{Case studies: Belarus experience in circular economy}

The Republic of Belarus faces a number of interrelated environmental and economic problems, such as climate change, waste generation and accumulation, degradation of ecosystems, air and water pollution, and reduction of biological diversity. According to international estimates, the Environmental Performance Index of Belarus for 2018 is $64.98 \%$ (ranked 44th out of 180 countries) (EPI, 2018). Unfortunately, Belarusian EPI ranking has lost nine positions compared to 2016 (Hsu et al., 2016).

In 2016 the National Plan of Action for the Green Economy (National Plan, 2016) was adopted in which the green economy was defined as a strategic priority of economic development. The development of the green economy was aimed at solving environmental problems, ensuring economic security and social stability, and creating additional conditions for the resumption of sustainable economic growth. Zenchanka and Korshuk considered the concept of green economy of Belarus (2015) and some results of its development (2017).

Classification of generated waste was adopted by the Resolution of the Ministry of Natural Resources and Environmental Protection No. 85 (Resolution, 2007). The classification includes more than 1,400 types of waste divided into the following groups (Review, 2016):

Waste of vegetable or animal origin;

Waste of mineral origin;

Waste from chemical plants and associated industries; Health-care waste;

Waste (sediments) from water treatment at boiler and heating facilities and for drinking, from treatment of sewage water, rainwater and from water use for power plants;

Municipal waste and similar waste from industries.

In 2017 "Belarus National Strategy for the Management of MSW and SMR till 2035" was adopted (Strategy, 2017). In accordance with this strategy, $40 \%$ of MSW must be reused in 2035 (15.6\% in 2015).

The development of the circular economy in the Republic of Belarus is of a non-permanent and non-systemic nature. Although some projects are implemented in different cities, at the legislative level the initiatives to introduce such economic model have not yet been discussed. When considering these projects in accordance with the EU Action Plan key areas, currently, the country is already implementing a number of such projects (Green Economy, n.d.).

Plastic wastes. According to various estimates, the content of plastic waste in household waste reaches $7 \%$ by weight in Belarus now. In Germany, for example, it is about $15 \%$. About 100 registered plastic waste recycling organizations registered in Belarus (Plastic waste, 2015) Plastic waste contains polyethylene terephthalate (PET, PET bottles), polyethylene (HDPE, LDPE) as well as polypropylene (PP). There are processing facilities in 
the Republic of Belarus for other types of plastic: polystyrene (PS), polyvinyl chloride (PVS), ABC-plastic. However, they are either limited or allow only the recycling of clean technological waste plastics.
Methods for recycling plastic waste depend on the type (brand) of plastic and waste origin. $17.4 \%$ of plastic waste was delivered from the common value of waste in 2015 and 32,5\% will be reused in 2020 (Strategy, 2017).

Table 2. Some activity on realization of Action plan on phasing out use polymer packaging

\begin{tabular}{l|l|c}
\hline \multicolumn{1}{|c|}{ No } & \multicolumn{1}{|c}{ Activity } & \multicolumn{1}{c}{ Terms } \\
\hline 1 & $\begin{array}{l}\text { Organization of separate collection of waste related } \\
\text { to secondary material resources }\end{array}$ & Constantly \\
\hline 2 & $\begin{array}{l}\text { Implementation of a deposit (pledge) circulation system of consumer } \\
\text { packaging }\end{array}$ & $2020-2021$ \\
\hline 3 & $\begin{array}{l}\text { Determination of the list of disposable plastic dishes, the use and sale of } \\
\text { which will be prohibited in catering facilities from January 1, 2021. }\end{array}$ & 2020 \\
\hline 4 & $\begin{array}{l}\text { Creating objects by sorting and using a solid municipal waste, including } \\
\text { recycling of plastic packaging waste }\end{array}$ & $2020-2022$ \\
\hline 5 & $\begin{array}{l}\text { Increase in production capacity for sorting mixed cullet as the existing } \\
\text { ones are loaded capacities }\end{array}$ & $2020-2022$ \\
\hline
\end{tabular}

An Action Plan has been developed to gradually reduce the use of polymer packaging with its replacement with environmentally friendly packaging (Resolution, 2020). Some activities and terms of implementation of this plan presented in the Table 2

It is seen that Plan activities focus on recycling and reducing the use of plastic and replacing it with more sustainable materials.

Food wastes. Food wastes include all types of food products that have lost consumer properties: defective food, the remains of meat/ dairy enterprises, remains of processing companies, spoiled food, leftover food from common eating places, wastes of individual consumption. The definition of waste used in Belarus encompasses a much more extensive range of materials than in international practice; it also includes by-products or materials, which can be reused in production on-site. Thus, the reported data on waste are not directly comparable with waste data from, for example, Western Europe (Review, 2016).

State sector companies and farms are the predominant forms of ownership; thus, it is expected that data collection cover most of them. Data on waste from agriculture and the food industry are stable, without recognizable shifts in methods of waste management (Review, 2016). The amount of waste recycled or given to others for secondary use is high; only about 10 per cent is sent for storage, treatment or disposal. This is also typical for waste from agriculture and the food industry in other countries. About half of the waste which cannot be recycled is sent for disposal and 25 percent is used as fuel (Review, 2016). Unfortunately, the State Program "Environmental Protection and Sustainable Use of Natural Resources for 2016-2020" (Program, 2016) does not contain provisions for waste management except hazardous waste, although such areas as recycling the plastics and construction waste and others require further development.

One of the components of the likely successful transition of the Republic of Belarus to a closed-cycle economy is organic agriculture and processing of food waste. Today, the country has created a full range of machinery for ecological agriculture. This includes (Agrostory, 2016):

Universal unit in 4 versions;

Technological line of cassette seedling production;

The unit for soil treatment in the rows of plants, sprouted mechanically destroys weeds with a simultaneous loosening the soil; 
The unit for shelter and removal of non-woven material of planted seedlings or sown seeds;

Two types of transplanters on a fundamentally new basis: they form wells in the soil, where water is dosed and seedlings are planted;

Installation of mulching polymer material of the soil surface.

Critical raw materials (CRM). The demand for CRMs, especially platinum group metals (PGMs), rare earth metals (REMs), silver and gallium in the strategic energy technologies sector alone is estimated to grow very rapidly until 2030. At the same time, the level of recycling of all the mentioned CRMs is lower than 11\% in comparison to their usage. As the demand for CRMs grows, it poses risks to the development of market prices and availability (European Commission, 2018).

Unitary enterprise "Unidragmet" of the Belarusian State University accepts precious metals in Minsk, and processes various scrap and waste containing precious metals with their subsequent extraction and delivery to the State Fund of precious metals and precious stones of the Republic of Belarus (Unidragmet, n.d.).

They accept:

Radio-electronic scrap (boards, capacitors, chips, connectors, resistors, transistors, diodes);

Technical silver (contacts of relays and electric starting equipment, ISS strings, etc.);

Catalysts (including automotive);

Scrap and waste of jewellery production, platinum scrap, thermocouples, wire;

Film-photo-X-ray materials (films and papers of various types and degrees of development);

Fixing and bleaching-fixing solutions;

Bulk waste (salt, ash, sludge and powders), etc.

The Decree (2012) of the President of the Republic of Belarus of July 11, 2012 No. 313 "On Some Issues of Consumption Waste Management" defined the principle of extended responsibility of producers and suppliers of plastic, glass, paper containers, as well as complex household appliances, batteries (batteries), lubricants, lighting devices and other things.

Construction and demolition. About three million tons of construction waste are generated in Belarus annually. These include the battle of reinforced concrete products, mixed construction waste, demolition of buildings and structures, the battle of ceramic bricks, asphalt concrete (Misyuchenko, 2018).

In accordance with the requirements of the Law of the Republic of Belarus "On waste management" (Law 2007), at the stage of developing the project documentation for construction, a set of measures for waste management should be provided, including the possibility of their subsequent use and transportation to relevant facilities. The level of use of construction waste in the republic is quite high and amounts to about $80 \%$. There are more than 190 objects in the register of waste utilization facilities (Ministry, n.d.).

The main product that is obtained as a result of the processing of construction waste is secondary crushed stone, which can be subsequently used both for the production of building materials and for the performance of planning work on construction sites and the rehabilitation of disturbed land.

Biomass and bio-based products. Bio-based products are products, which are wholly or partly derived from biomass. Therefore, it is essential to characterize the amount of biomass contained in the product.

Composting of the biodegradable fraction of MSW is not yet developed in Belarus as a component of the waste management infrastructure, nor are there targets in waste management programmes.

One of the most interesting projects in this field is the project "Development of the forest sector of the Republic of Belarus", implemented through a loan from the World Bank (40.7 million US dollars) and a related grant from the Global environment facility (2.7 million US dollars). In 2018, the World Bank allocated an additional $€ 12$ million to finance the Belarus Forestry Development Project (World Bank, 2015). This project will support further development and intensification of silviculture, including the purchase of 74 modern forest harvesters, needed for younger-aged thinning operations, and 52 forwarders. Six new heavy-duty chippers will help to utilize wood waste and woody biomass from felling and logging operations, which currently are left in the forest to rot, wasting the calorific value therein and creating a fire hazard. 


\section{Conclusions}

Separate collection and recycling, safe disposal of hazardous wastes are essential steps towards improving the environment. An even more important step is the prevention of waste generation - when instead of throwing out a thing that no longer has an immediately identifiable use, the values underpinning the circular economy will encompass this 'waste product' into a raw material.

The Republic of Belarus has highly developed industrial and agricultural sectors, which are the basis of the economy however, they both leave a significant environmental footprint. Environmental improvement and sustainable management of natural resources are among the main long-term priorities of national policy. The Republic of Belarus makes progress in the fulfillment of the green economy principles and tasks. Considering the economy of Belarus, Batova and Tochitskaya (2020) described it to a greater extent corresponding to the traditional (linear) model (19.4\%), rather than circu$\operatorname{lar}(48.2 \%)$, while recognizing the existence of successful, but single circular enterprises (16.9\%).

At the same time, there are some difficulties in the implementation of the circular economy principles. Sufficient progress in the implementation of key areas of European Union Action Plan such as plastic wastes, construction, demolition and food waste can be noted. Specific steps are also made in extracting the critical raw materials.

\section{References}

Action Plan (2015) Communication from the commission to the parliament, the council and the European economic and social committee and the committee of the regions: Closing the loop - An EU action plan for the Circular Economy. COM (2015) 614 final. European Commission.AFNOR standardisation (n.d.) Circular economy and voluntary standard - 6 organizations recount their experience! Available at: https://www.afnor.org/ en/ (accessed 20 August 2020).

Agenda 21 (1992) The Rio Declaration on Environment and Development, Available at: https://sustainabledevelopment.un.org/ content/documents/Agenda21.pdf (accessed 25 June 2020).
It should be noted, that the results of waste management in Belarus and the European Union are not comparable. First of all, this is related to the differences of waste definitions, their classification, as well as the lack of sufficient statistical information, since various authorities collect this information..

In recent years, the Republic of Belarus has taken a number of measures aimed at improving the environmental situation, in particular, the National Plan for the Development of a Green Economy (2016), National Strategy on the management of solid communal waste and secondary material resources in the Republic of Belarus for period until 2035" (Strategy, 2017) and Resolution (2020) of the Council of Ministers of the Republic of Belarus" About phasing out use polymer packaging". The implementation of these measures will allow the Republic of Belarus to take the next steps to achieve the goals of the "green" and "circular" economies

\section{Acknowledgements}

The authors thank our colleagues from the Minsk Branch of the Plekhanov Russian Economic University for their useful discussion of the article and Prof. Walter Leal Filho (Hamburg University of the Applied Science) for his review and recommendation.
Agrostory (2016) New design of agriculture machinaries in Belarus oriented on intellectual agriculture. Available at: https:// agrostory.com/info-centre/market-news/new-development-of-agricultural-machinery-in-belarus-is-focused-on-intelligent-agriculture/ (accessed 15 July 2020).

Batova N., Tochitskaya I. (2020) How Belarusian business understands the concept of a circular economy: a study using the method of repertoire gratings. BEROC Green Economy Policy Paper Series, PP no.13. Available at: http://www.beroc.by/ upload/iblock/068/068eaa2d3e4e17ec86f7047cf0d1c0bc.pdf (accessed 20 August 2020). 
Briefing (2018) Circular economy package. Four legislative proposals on waste. European Parliament. EU Legislation in Progress. Available at: http://www.europarl.europa.eu/RegData/ etudes/BRIE/2018/614766/EPRS_BRI(2018)614766_EN.pdf (accessed 25 June 2020).

Brief News (2019) European Standards, contributing to the implementation of Circular Economy. Available at: https://www. cencenelec.eu/News/Brief_News/Pages/EN-2019-050.aspx (accessed 25 June 2020).

Brundtland Report (1987) Our Common Future. Report of the World Commission on Environment and Development. United Nations.

Circular Economy Package (2018) Key documents/ Available at: https://ec.europa.eu/environment/circular-economy/first_circular_economy_action_plan.html (accessed 15 November 2020).

Communication (2018) Communication from the commission to the parliament, the council, the European economic and social committee and the committee of the regions on a monitoring framework for the circular economy. SWD (2018)17 final. European Commission. Strasbourg. Available at: http:// ec.europa.eu/environment/circular-economy/pdf/monitoring-framework.pdf (accessed 25 June 2020).

Declaration (2012) The Future We Want. Outcome document of the United Nations Conference on Sustainable Development. Rio de Janeiro, Brazil, 20-22 June 2012. United Nation.

EASAC (European Academies Science Advisory Council) (2016) Indicators for a circular economy. Available at: www.easac.eu (accessed 25 June 2020).

Ellen MacArthur Foundation (2012) Towards the Circular Economy: Economic and Business Rationale for an Accelerated Transition. Available at: https://www.ellenmacarthurfoundation. org/assets/downloads/publications/Ellen-MacArthur-Foundation-Towards-the-Circular-Economy-vol.1.pdf (accessed 25 June 2020)

EPI (2018) 2018 Environmental Performance Index Results. Available at: https://epi.envirocenter.yale.edu/epi-topline (accessed 20 January 2020).

"European Commission (2018) Report on Critical. Raw Materials in the Circular Economy"

Hsu A. et al. (2016). 2016 Environmental Performance Index. New Haven, CT: Yale University. Available: www.epi.yale.edu (accessed 20 January 2020).

Forrester J.W. (1971) World Dynamics. Cambridge, Mass., Wright-Allen Press. 142 p.

Green Economy (n.d.) Available at: http://www.economy.gov. by/en/green_economy-en/) (accessed 15 July 2020).
Kalmykova Yu., Sadagopanb M. and Rosadoc L. (2018) Circular economy - From review of theories and practices to development of implementation tools. Resources, Conservation and Recycling 135, August 2018, Pages 190-201. https://doi. org/10.1016/j.resconrec.2017.10.034

Kirchherr J., Reike D. and Hekkert M (2017) Conceptualizing the circular economy: An analysis of 114 definitions. Resources, Conservation and Recycling 127, pp. 221-23. https://doi. org/10.1016/j.resconrec.2017.09.005

Korhonen J., Nuur C., Feldmann A. and Birkie S.E. (2018a) Circular economy as an essentially contested concept. Journal of Cleaner Production. 175, 544-552. https://doi.org/10.1016/j. jclepro.2017.12.111

Korhonen J., Honkasalo A. and Seppälä J. (2018b) Circular Economy: The Concept and its Limitations. Ecological Economist 143, 37-46. https://doi.org/10.1016/j.ecolecon.2017.06.041

Korten DC (2015) Change the Story, Change the Future: A Living Economy for a Living Earth. Berrett-Koehler Publishers. Oakland, CA. USA.

Law (2007) The Law of the Republic of Belarus on 20 July 2007 № 271-3 "On Waste Management" Available at: http://pravo. newsby.org/belarus/zakon0/z695.htm (accessed 10 January 2020) (in Russian).

Meadows DH, Meadows DL, Randers J, Behrens III WW (1972) Limit to growth. Universe Books. New York. USA. 211 p.

Ministry (n.d.) Ministry of Natural Resources and Environmental Protection of Belarus. Waste management. Available at: https://www.minpriroda.gov.by/ru/otxody-ru/ (accessed 20 August 2020) (in Russian).

Misyuchenko V.M. (2018) Industrial waste processing and development of documents for the enterprise - Minsk. 99 p. (in Russian).

Mouyal N (2020) Applying standards to the circular economy. Material efficiency during the product use and waste phases. E-tech. 2, Available at: https://etech.iec.ch/issue/2020-02/ applying-standards-to-the-circular-economy (accessed 20 July 2020).

Naden C. (2019) Connecting the dots in a circular economy: a new ISO technical committee just formed. ISO News. Available at: https://www.iso.org/news/ref2402.html (accessed 20 July 2020).

National Plan (2016). National plan actions to develop a "green" of Economy in the Republic of Belarus until 2020. Available at: https://www.economy.gov.by/uploads/files/1061r.pdf (Accessed 22 September 2019) (in Russian).

OECD (The Organisation for Economic Co-operation and Development) (2017) Green Growth Indicators 2017, Highlights, 
OECD Green Growth Studies, OECD Publishing, Paris. Available at: https://doi.org/10.1787/9789264268586-en

PAGE (Partnership for Action on Green Economy) (2016) Green Economy Learning Assessment South Africa: Critical Competencies for Driving a Green Transition.

PAGE (2017) Green Economy Inventory for South Africa: An Overview. Pretoria. South Africa.

PAGE (2018) A Green Economy Industry and Trade Analysis: Assessing South Africa's Potential.

Pauliuk S. (2018) Critical appraisal of the circular economy standard BS 8001:2017 and a dashboard of quantitative system indicators for its implementation in organizations. Resources, Conservation and Recycling. 129, Pages 81-92. https://doi. org/10.1016/j.resconrec.2017.10.019

Pearce D., Markandya A. and. Barbier EB (1989). Blueprint for a Green Economy. Earthscan Publication. London.

Plastic waste (2015) Plastic waste: what to collect, where to dispose of, hand over. Available at: http://target99.by/infopost. php?id=7 (accessed 15 September 2020)

Platform (2015) Transforming our world: the 2030 Agenda for Sustainable Development. United Nations - Sustainable Development knowledge platform. Available at: https://sustainabledevelopment.un.org/post2015/transformingourworld. (accessed 15 July 2020).

Potting J, Hekkert M., Worrell E. and Hanemaaijer A. (2017) Circular Economy: Measuring Innovation in the Product Chain. Available at: http://www.pbl.nl/sites/default/files/cms/ publicaties/pbl-2016-circular-economy-measuring-innovation-in-product-chains-2544.pdf (accessed 25 June 2018).

Program (2016) The State Program of the Republic of Belarus "Environmental Protection and Sustainable Use of Natural Resources for 2016-2020" Available at: http://www.minpriroda. gov.by/ru/gosprog/ (accessed 15 January 2019) (in Russian).

Resolution (2007) of the Ministry of Natural Recourses and Environmental protection on of the Republic of Belarus on 8 November 2007 "On approving the classificatory of waste forming in the Republic of Belarus' Available at: Available at: http:// sifania.by/novosti/klassifikator-otkhodov/klassifikator-otkhodov-obrazuyushchikhsya-v-respublike-belarus (accessed 10 January 2019) (in Russian)

Resolution (2020) of the Council of Ministers of the Republic of Belarus on 13 January 2020 No 7 "About phasing out use polymer packaging" Available at: https://pravo.by/upload/docs/ op/C22000007_1579035600.pdf (accessed 15 July 2020).

Review (2016) Environmental Performance Review. Belarus. Third Edition. United Nation. New York and Geneva, 2016. 379 P.
Statistical book (2019) Energy balance of the Republic of Belarus. National statistical committee of the Republic of Belarus. Minsk.

Statistical Yearbook (2020) National Statistical committee of the Republic of Belarus. Minsk. Available at: https://www.belstat. gov.by/upload/iblock/7d0/7d0ed3586722991264205df8d056cf60.pdf (accessed 10 November 2020).

Strategy (2017) National Strategy on the management of solid communal waste and secondary material resources in the Republic of Belarus for period until 2035. Available at: https:// www.mjkx.gov.by/vtorichnye-mat-resursy/item/481-natsionalnaya-strategiya (accessible 25 July 2020) (in Russian).

von Weizsäcker E.U., Lovins A.B. and Lovins L.H. (1998) Factor Four. Doubling Wealth, Halving Resource Use. The new report of the Club of Rome. Earthscan, $322 \mathrm{P}$.

von Weizsäcker E.U., Hargroves K.C., Smith M.H., Desha C. and Stasinopoulos P. (2009) Factor Five: Transforming the Global Economy Through 80\% Improvements in Resource Productivity: a Report to the Club of Rome. Earthscan, 431 P. https://doi. org/10.4324/9781849774475

UNDESA (United Nations Department of Economic and Social Affairs) (2012a) A guidebook to the Green Economy. Issue 1: Green Economy, Green Growth, and Low-Carbon Development - history, definitions and a guide to recent publication. UNDESA. UNDESA (2012b) A Guidebook to the Green Economy Issue 2: exploring green economy principles. UNDESA.

UNDESA (2012c) A Guidebook to the Green Economy. Issue 3: exploring green economy policies and international experience with national strategies. UNDESA.

UNDESA (2013) A Guidebook to the Green Economy. Issue 4: A guide to international green economy initiatives. UNDESA.

UNEP (The United Nations Environment Programme) (2011) Towards a Green Economy: Pathways to Sustainable Development and Poverty Eradication, Available at: www.unep.org/ greeneconomy (Accessed 22nd September 2018).

UNEP (2015) Multiple Pathways to Sustainable Development: Initial findings from the Global South. 59 p.

UNEP (2016) The Emissions Gap Report 2016. United Nations Environment Programme (UNEP), Nairobi.

UNEP (2017) The Emissions Gap Report 2017. United Nations Environment Programme (UNEP), Nairobi.

Unidragmet (n,d,) Servicies Available at: (http://unidragmet.by/ uslugi/pererabotka-loma-i-otkhodov-dragmetallov (available 20 November 2020) (in Russian).

Witjes S. and Lozano R. (2016) Towards a more Circular Economy: Proposing a framework linking sustainable public procurement and sustainable business models. Resources, Con- 
servation and Recycling 112, September 2016, Pages 37-44V. https://doi.org/10.1016/j.resconrec.2016.04.015

Wijkman A.. and Skånberg K (2016) The Circular Economy and Benefits for Society. Jobs and Climate Clear Winners in an Economy Based on Renewable Energy and Resource Efficiency. Club of Rome. Available at: https://www.clubofrome.org/wp-content/uploads/2016/03/The-Circular-Economy-and-Benefits-for-Society.pdf (accessed 25 June 2020).

World Bank (2015) World Bank Supports Forests Protection and Development in Belarus/ Available at: http://www.worldbank. org/en/news/press-release/2015/03/27/world-bank-forests-protection (accessed 20 July 2020).

Zenchanka S. and Korshuk E. (2015) The 'green economy' concept in Belarus: Today and tomorrow. Progress in Industrial Ecology, An Int. J., 2015 Vol.9, No.1, pp. 33 - 45. https://doi. org/10.1504/PIE.2015.069839

Zenchanka S. and Korshuk E. (2017) The Development of green economy in Belarus: 2016-2020 National plan. Annals of the "Constantin Brâncuşi" University of Târgu Jiu, Economy Series", Issue 4/2017, pp. 35 - 42. 